\title{
В одном строю: иностранные медсестры Немецкого Красного креста, награжденные в период Второй мировой войны*
}

Аннотация статьи: В настоящей работе нами была предпринята попытка рассмотреть некоторые эпизоды награждений иностранных медсестер, проходивших службу в рядах Немецкого Красного креста в период Второй мировой войны.

Zarys treści: W pracy autor spróbował przeanalizować niektóre z epizodów odznaczenia pielęgniarek cudzoziemek, służących w szeregach Niemieckiego Czerwonego Krzyża w okresie II wojny światowej.

Outline of content: The purpose of the present study is to examine the cases of foreign nurses working for the German Red Cross during World War II who were awarded Nazi medals for their service.

Ключевые слова: иностранные медсестры Немецкого Красного креста, медицинская служба в период Второй мировой войны, Вторая мировая война

Słowa kluczowe: pielęgniarki cudzoziemki Niemieckiego Czerwonego Krzyża, służba medyczna w okresie II wojny światowej, II wojna światowa

Keywords: foreign nurses of the German Red Cross, medical service during World War II, World War II

Медицинская служба является одной из наиболее важных составляющих военной машины любого государства, как в мирное время, так и в период военных действий. Служба женщин в ее рядах имеет долгую историю,

\footnotetext{
* Автор выражает искреннюю благодарность за помощь и предоставленный материал Виму Винкелеру (Бельгия) и Патрику Агте (Германия). / Autor pragnie przekazać wyrazy szczerej wdzięczności za pomoc i udostępniony materiał Wimowi Winkelerowi (Belgia) i Patrickowi Agte (Niemcy). / The author expresses his sincere gratitude for aid and material provided to Wim Winkeler (Belgium) and Patrick Agte (Germany).
} 
достаточно вспомнить легендарную британскую сестру периода Крымской войны 1853-1856 гг. Флоренс Найтингейл. Однако наибольшие масштабы практически во всех странах-участницах она приняла именно в ходе второй мировой войны.

Не была исключением в этом отношении и Германия - согласно закону от 9 декабря 1937 г., в период войны женщины и девушки заменяли мужской персонал и несли службу в медицинских учреждениях вооруженных сил. Оставаясь сотрудницами гражданской организации, они кроме формы получали личный опознавательный знак установленного Верховным командованием Вермахта образца, личную книжку (нем. Verwendungsbuch) - аналог солдатской книжки военнослужащего и соответствующую стандартам Женевской конвенции нарукавную повязку. Они несли службу в лазаретах, санаториях для выздоравливающих, санитарных поездах при установленной норме рабочего времени в 60 часов в неделю. Последнее, однако, в условиях театра боевых действий зачастую не соблюдалось ${ }^{1}$.

При этом все рода войск германской армии, а также войска СС имели лазареты, укомплектованные собственным медицинским персоналом (врачами и санитарами), однако весь штат сестер (то есть штатных сотрудниц, состоявших в одном из сестричеств) и сестер-хелферин (добровольно вступивших на службу с началом войны и прошедших курс медицинской подготовки девушек) числился исключительно в составе Немецкого Красного креста ${ }^{2}$.

Без сомнения, присутствие женщин в военной среде привлекало повышенное внимание солдат, что зачастую приводило к неловким или курьезным моментам. Так, голландский доброволец Войск СС Хендрик Вертон впоследствии иронически описывал процедуру дезинфекции новоприбывших при поступлении в госпиталь:

Мы были настоящей живой лентой конвейера для «карболовых ангелов» - медсестер, готовых мазать каждую покрытую волосами часть нас дезинфицирующим маслом. Это вызывало проблемы у тех, кто месяцами не видел женщин. Они оказывались в центре поддразниваний, ухмылок, смеха и комментариев от своих товарищей, которые сестры дипломатично игнорировали, выполняя свой долг с легкой улыбкой на губах ${ }^{3}$.

Ветеран 6-й горной дивизии войск СС «Норд» Йохан Фосс так же впоследствии вспоминал:

1 Schweizer J. Les auxiliaries de la Deutsches Rotes Kreuz. Uniforme et équipement, 1938-1945 // «Armes Militaria Magazine» № 314, Septembre 2011. P. 33.

2 Williamson G. World War II German Women's Auxiliary Services. Oxford, 2003. P. 33.

3 Verton $H$. In the fire of the Eastern front: the experiences of a Dutch Waffen-SS Volunteer, 1941-45. Mechanicsburg, 2010. P. 103. 
Потом, сидя там [в «Солдатском доме» - А.С.] и куря, я смотрел на двух сестер Красного креста, работавших в баре и весело разговаривавших с солдатами. Просто возможность видеть реальных молодых женщин и слышать их мягкие голоса вызвала смятение внутри меня. Я не был рядом ни с одной женщиной долгое время там [на передовой - А.С.]. Я сидел в своей пятнистой боевой блузе и не сильно чистых брюках. Наблюдая за ними в их безупречных светло-серых платьях с белыми фартуками и воротничками, среди общей опрятности места, я начал понимать, о чем Генрих предупреждал меня - я чувствовал себя лишним. Когда одна из сестер проходила мимо моего стула так близко, что задела мое лицо своим платьем, я оказался в полном смущении. Я быстро встал и сбежал в кино ${ }^{4}$.

Отсутствие оружия и статуса военнослужащих не избавляло девушек от всех ужасов войны. Наравне с мужчинами они оказывались в эпицентре боевых действий на фронте, нападений партизан и повстанцев, налетов авиации и несли тяжелые потери.

В качестве примера можно привести эпизод, когда 11 февраля 1943 г. части советского 4-го гвардейского танкового корпуса неожиданным броском захватили важный узловой населенный пункт Красноармейское в современной Донецкой области Украины. Прежде чем 19 февраля прорвавшаяся советская группировка была уничтожена, а город отбит немецкими войсками, военнослужащими Красной армии в нем были убиты более 600 военнопленных, включая медсестер Красного креста и хелферин службы связи.

Благодаря немедленно начатому военно-судебному расследованию, по неполным данным, удалось индивидуально опознать тела 406 немецких, 89 итальянских, 9 румынских, 4 венгерских, 8 украинских солдат, 58 служащих организации Тодта, 15 железнодорожников и 7 немецких гражданских. В протоколе следствия говорится, что все трупы были голые, почти все тела были изувечены, у многих были отрезаны носы и уши, у других отрезаны и засунуты в рот половые органы. В случае с убитыми сестрами Красного креста была так же предпринята попытка «зверским образом» отрезать груди.

Согласно показаниям взятого в плен командира зенитной батареи 14-й гвардейской танковой бригады лейтенанта Сорокина, ответственность за это преступление нес, в частности, политотдел данной бригады ${ }^{5}$ которой в период этих боев командовал гвардии подполковник Василий Шибанков, убитый 19 февраля 1943 г $^{6}$.

4 Voss J. Black Edelweiss. A Memoir of Combat and Conscience by a Soldier of the Waffen SS. Bedford, 2002. P. 114.

5 Гофман И. Сталинская война на уничтожение: планирование, осуществление, документы. М., 2006. С. 296-297.

${ }^{6}$ Центральный архив Министерства обороны Российской Федерации (ЦАМО РФ). Ф. 58. Оп. 18001. Д. 1311. Л. 4. 
Согласно официальным советским данным, за восемь дней боев в районе города были захвачены 612 военнопленных (501 из которых - 11 февраля). Вероятно, именно таково точное количество убитых 7 .

Подобные эпизоды на Восточном фронте были повсеместны. Например, во время боев в Будапеште, в захваченном немецком военном госпитале, размещавшемся в здании современной библиотеки имени Сеченьи, советские солдаты не только искали среди раненых русских и украинских добровольцев Вермахта и СС, убивая всех, кто не мог ответить по-немецки, и кидали ручные гранаты в палаты, но также изнасиловали и зарезали нескольких медсестер ${ }^{8}$.

Общая тенденция массового привлечения на службу иностранных добровольцев из оккупированных, союзных и нейтральных стран, характерная для Германии периода Второй мировой войны, коснулась не только мужчин, но также женщин и девушек. В частности, ряды Немецкого Красного креста пополнили несколько тысяч норвежских, голландских, фламандских, датских, валлонских, французских, испанских, украинских, русских, латвийских, эстонских медсестер.

Наряду со своими немецкими сослуживицами они вносили немалый вклад в общие военные усилия Германии, что выразилось, в том числе, в значительном количестве полученных ими наград Рейха. Рассмотрение данного, крайне актуального в силу своей малоизученности, вопроса будет являться целью нашей работы.

\section{Награждение иностранных медсестер Железным крестом II класса}

Один из самых крупных контингентов медсестер Немецкому Красному кресту дала Норвегия, где данные девушки (как и в соседней Дании) получили название «фронтовых сестер» (норв. Frontsøstre).

В ряде старых работ можно встретить оценки численности норвежских сестер в 350-400 человек9. Однако гораздо более заслуживающими доверия представляются сведения норвежского специалиста Андерса Гогстада, согласно которым их число могло достигать 500. Он же приводит данные бывшего СС-ротенфюрера 23-го танково-гренадерского полка «Норге» Кнута Бордсетха о 432 поименно известных фронтовых сестрах ${ }^{10}$.

7 Там же. Ф. 3402. Оп. 1. Д. 60. Л. 66, 77.

8 Ungváry K. Battle for Budapest. One Hundred Days in World War II. London; New York, 2003. P. 274.

9 Blindheim S. Frontkjemperbevegelsen. Hovedoppgave i Historie.Universitetet i Oslo, 1974. S. 92; Neulen H. W. An deutscher Seite. Internationale Freiwillige von Wehrmacht und Waffen-SS. München, 1992. S. 155.

10 Gogstad A. Gjemt eller glemt? Norske kvinner i tysk sanitetstjeneste under Den annen verdenskrig // «Michael» № 5, 2008. S. 307-308. 
По имеющимся данным, 21 из них погибла ${ }^{11}$, а одна - родившаяся 9 ноября 1914 г. в Нарвике Анна Гунхильд Мокснес - получила Железный крест II класса, став первой иностранкой, отмеченной этой наградой ${ }^{12}$.

Она входила в состав первого контингента норвежских медсестер, отбывших на Восточный фронт в первой половине 1942 г. Кроме нее группа включала сестер Магнхилл Фьерли (получившую прозвище «Макси»), Марту Елиассен («Кнопка»), Берту Гулигсен, Йергину Фэллинг, Ванду Корведофф, Магну Скьекермо, Сигне Хоел, Грету Штольц, Руфь Хоел, Магнхилд Лангфелдт, Гудрун Херигстад, Эльзу Стендал, Рагну Хелену Восс, Эльзу Хиркебю, Герд Элвебаккен («Бабс»), Ингрид Энгенесс, Эстер Рекке, Грету Бротен, Мари Вильхельмсен, Ингер Эуне, Анну Марию Бьернстадт, Герд Энод, Марию Ингебритсен, Венке Варендорпф. Позже к ним в Кисловодске присоединились Рангхилд Спокели и Соня Крей, а в Мариенбаде - Бьерг Лилиан Фроссли, Марта Саннли, Грета Гасман (пропала без вести в 1945 г.), Карен Инга Хоффгорд Буде (погибла под Ленинградом) $)^{13}$.

Первоначально Анна служила при дивизии СС «Викинг», в том числе в период наступления на Кавказ. Последовательно работала в госпиталях Днепропетровска, Кисловодска, баварского Рупольдинга, лазарете III корпуса CC (SS Korpslazarett 1/103) в Мариенбаде и Таллинне, в конце войны - в померанском Хаммерштейне ${ }^{14}$.

Железный крест ей принесли ее действия во время массированного советского авианалета на Таллинн в ночь с 9 на 10 марта 1944 г. $^{15}$ : рискуя жизнью, Мокснес всю ночь, в одной ночной рубашке и сапогах, выносила раненых солдат из горящего здания ${ }^{16}$.

Кроме того, норвежским правительством медсестра была награждена почетным Знаком фронтовика (норв. Frontkjempermerket), который был вручен ей в Осло 15 сентября 1944 г., и Знаком фронтовой сестры (норв. Frontsøstremerket $)^{17}$.

После войны Мокснес была приговорена к 15 месяцам тюремного заключения за службу на Восточном фронте и к 3 годам - за членство в норвежской

${ }^{11}$ Fonn M. - Unnskyld, frontsøstre! // «Sykepleien» № 3, 12 mars 2015. S. 88.

12 Klietmann K.-G. Auszeichnungen des Deutschen Reiches 1936-1945. Stuttgart,2004. S. 31.

13 Hvorfol svek du oss - Nøklebye Heiberg? Den første kontigent frontsøstre / «Folk og Land» № 3, 1998. S. 12.

14 Gripp Bay E. Historien om frontsøstrene. De norske frontsøstrenes historie i et nytt lys. Masteroppgave i historie. Universitetet i Oslo, november 2014. S. 72.

15 DRK.-Schwestern - im Fronteinsatz bewährt / «Znaimer Tagblatt» № 289, 7 Dezember 1944. S. 3; Klietmann K.-G. Auszeichnungen des Deutschen Reiches... S. 31.

16 Fonn M. - Unnskyld, frontsøstre! // «Sykepleien» № 3, 12 mars 2015. S. 88.

17 Taylor H. P. Vichinghi contro il bolscevismo. Il distintivo norvegese per I combattenti al fronte: in Frontkjempermerket // «Uniformi \& Armi» № 164, Dicembre 2009. S. 10; Norske kvinner pleiet Hitlers soldater ved Østfronten. 70 år etter vekker innsatsen strid / «Dagbladet» http:// www.skivebom.com/lastned/historie/frontsøstre_dagbladet_pluss.pdf Режим доступа: 14.06.2016. 
национал-социалистической партии «Национальное единение». После освобождения в 1949 г. с трудом смогла устроиться на работу в больницу Улевол в Тронхейме ${ }^{18}$.

Впоследствии была ректором и Первым преподавателем школы медсестер в том же городе. Выпускницы школы вспоминали о ней как очестной, очень простой, серьезной, прямой, умной и спортивной женщине ${ }^{19}$. Мок снес гордилась их успехами, сама никогда не создала семьи и не имела детей. Говоря о своем прошлом, она ни о чем не сожалела и не отказывалась от прежних взглядов. Умерла в 1994 г. в возрасте 80 лет $^{20}$.

Имя еще одной медсестры-иностранки, получившей Железный крест II класса, нам, к сожалению, неизвестно. Ее упоминает в своих мемуарах бывший командир 28-й добровольческой гренадерской дивизии СС «Валлония» СС-штандартенфюрер Леон Дегрелль. Во время ожесточенных боев за город Штеттин в Померании, в марте 1945 г., данная валлонская медсестра, будучи вдовой, потеряла трех своих сыновей. Однако она просила Дегрелля не отправлять ее в тыл, а оставить на поле боя, где погибли ее дети. В итоге, оказывая под советским огнем помощь раненым, она заслужила Железный крест ${ }^{21}$.

В последние месяцы войны широкую известность получил факт упорной обороны крупного силезского города Бреслау - несмотря на постоянные штурмы, советским войскам с февраля 1945 г. до самого конца войны не удалось сломить сопротивление многократно уступавшего в численности личного состава и техники блокированного немецкого гарнизона, испытывавшего, кроме того, проблемы со снабжением. В период данных боев целый ряд медсестер был награжден Железными крестами II класса. Среди них известны, по крайней мере, две иностранки.

Первой была «юная и светловолосая» хелферин Лилиан Соренсен, 19-летняя датчанка из Копенгагена.

Она прибыла в Германию осенью 1943 г. для работы в сельском хозяйстве в рамках «Земельной службы» Гитлерюгенда. В июле следующего года Лилиан записалась в Немецкий Красный крест, так как, по ее собственным словам, «ее единственным желанием было помогать солдатам», а еще через несколько месяцев была направлена из Куксхафена в Бреслау, куда прибыла 21 декабря 1944 г. Там молодая датчанка сама изъявила желание служить на передовой в одном из оборонявших город батальонов. В его рядах под советским артиллерийско-минометным огнем девушка проявила себя лучшим образом, а 26 февраля 1945 г. получила сквозное ранение осколком

${ }_{18}$ Fonn M. - Unnskyld, frontsøstre! // «Sykepleien» № 3, 12 mars 2015. S. 88.

19 Fonn M., Hernoes N., Hofstad E. Hva skjedde med 1967-kullet? // «Sykepleien» № 18, 6 desember 2007. S. 29.

${ }^{20}$ Fonn M. - Unnskyld, frontsøstre! // «Sykepleien» № 3, 12 mars 2015. S. 88.

${ }^{21}$ Degrelle L. Campaing in Russia. The Waffen SS on the Eastern Front. Institute for historical review, 1985. P. 308. 
минометного выстрела, влетевшим через окно подвала, где она находилась. Однако после оказания помощи она отказалась от госпитализации, сказав чуть позднее военному корреспонденту Хансу-Иоахиму Герцегу: «Пока я могу ходить, я останусь». Кроме Железного креста II класса Соренсен получила также знак «За ранение» (вероятно, черный) ${ }^{22}$.

Второй награжденной Железным крестом за оборону Бреслау медсестрой-иностранкой стала фламандка Люция Лефевер, родившаяся 7 сентября 1925 г. в городке Эльвердинг под Ипром и вступившая в Немецкий Красный крест в августе 1943 г. (на тот момент проживала в Брилене, Веурнстраат 158) 23 . В послевоенных документах бельгийских судебных органов она фигурирует как Люсьена (полное имя - Люсьена Мария Корнелия), однако в работе мы будем использовать вариант «Люция», встречающийся в большинстве известных нам источников.

Лефевер родилась в патриотически-настроенной фламандской семье и являлась членом национал-социалистической молодежной организации «Союз голландских девушек». Этим объяснялась ее мечта служить медсестрой на Восточном фронте. Трехмесячную учебную практику после зачисления она проходила в Тюрингии, из-за болезни пропустила экзамен и сдавала отдельно от своих фламандских сокурсниц вместе с медсестрами-немками. Однако, несмотря на эти трудности, она смогла сдать его с отличием. В итоге, после периода службы в Бад-Зальцунгене, Люция была отправлена в Лиссу под Бреслау, где получила назначение в аптеку ${ }^{24}$.

По ее воспоминаниям, их лазарет в ночь с 20 на 21 января 1945 г. был поднят по тревоге и эвакуирован от линии фронта в Кляйн-Бессу под Бреслау, где разместился на ночь в местной школе. На следующий день они были переброшены в замок Грифене, в 1 км за Одером, где был оборудован импровизированный полевой госпиталь. Поток раненых был огромен, и размещать их приходилось в коридорах и подвалах, из-за нехватки кроватей укладывая на солому. Запасов медикаментов, инструментов и перевязочных средств не хватало. В замке лазарет Люции дислоцировался до 17 февраля, когда, в связи с сужением кольца блокады, их перевели ближе к центру города, в одно из мало приспособленных для этих целей зданий. При этом раненых перевозили на гужевых повозках 25 .

Длительное время гарнизону удавалось удерживать аэродром, который был захвачен Красной армией лишь в Пасхальный понедельник 11 апреля. На обратном пути самолеты, осуществлявшие снабжение, забирали раненых, гражданских и командированных. Таким образом, с 15 февраля до

${ }^{22}$ Kriegsberichter Hansjoachim Herzog Dänische DRK.-Helferin erhielt das EK. 2 / «Schlesischen Tageszeitung» № 71, 16 März 1945.

23 «Belgisch Staatsblad», 1 november 1946. P. 9036.

${ }^{24}$ Ein flämisches Mädchen mit EK 2 // «Der Freiwillige» № 1, Januar/Februar 2013.

25 Vincx J. Vlamingen aan het Oostfront. Deel 2. Antwerpen, 1975. P. 241. 
27 марта из города были эвакуированы 3692 раненых (не считая вывезенных 23 и 27 марта), 123 здоровых военнослужащих (в том числе генерал-майор Ханс фон Альфен), 230 гражданских и 3 курьера ${ }^{26}$.

Сопровождать тяжелораненых должны были медсестры из числа несовершеннолетних. Однако, как вспоминала Лефевер: «Я не верю, что среди нас были те, кто считал возможным оставить своих пациентов», поэтому девушки старались отказаться от этой возможности, при каждом рейсе мечтая, чтобы полетел кто-то другой.

Медицинское подразделение, в котором кроме Люции служили врач и еще несколько медсестер, входило в состав крепостного полка оберштурмбанфюрера СС Георга Роберта Бесслейна. Постоянно находясь под огнем, оно неоднократно меняло места своей дислокации, последним из которых стал комплекс «Зал столетия». Работа практически не прекращалась - если сестры не занимались непосредственно ранеными, они находились на кухне или в прачечной, стерилизуя бинты и медицинские инструменты.

Служба в подобных условиях принесла Люции Железный крест II класса, который она получила 10 марта 1945 г. на командном пункте полка из рук оберштурмбанфюрера Бесслейна.

Появившееся в 20.005 мая сообщение о капитуляции гарнизона вызвало потрясение среди сослуживцев девушки: «Весь ад был ничто по сравнению с этим смертным приговором». Она, еще одна медсестра-голландка, врач-стоматолог, фламандский санитар и несколько легкораненых решили не сдаваться и попытаться выбраться из города. Они шли в течение двух ночей, днем прячась в руинах, однако на второй или третий вечер столкнулись с советским патрулем и были захвачены в плен. До 22.00 следующего дня они непрерывно двигались в колонне военнопленных в неизвестном направлении. Конвоиры убивали всех, кто отставал или не мог идти. Так погибли многие пожилые фолькштурмисты.

До августа 1945 г. Люция находилась в концентрационных лагерях, работая в поле и подвергаясь побоям и насилию, пока на нее не обратила внимания советская женщина-офицер, для которой фламандская медсестра сшила платье, за что получила дополнительное питание. Затем она вместе с другими иностранцами была поездом отправлена в Магдебург, где их обменяли на прибывавших с Запада советских военнопленных. Последние, не желая возвращаться в СССР, упорно сопротивлялись, взявшись за руки, и их приходилось растаскивать силой, чтобы обмен состоялся. Прибывшие были разделены по национальным лагерям (фламандцы попали в бельгийский) и после трехнедельного пребывания там отправлены в Бельгию, где, по словам Лефевер, «наш «дом», опять же, означал плен» ${ }^{27}$.

26 Solarz J. Breslau 1945. Warszawa, 2007. S. 54.

27 Vincx J. Vlamingen aan het Oostfront. Deel 2... P. 241-242; Ein flämisches Mädchen mit EK 2 // «Der Freiwillige» № 1, Januar/Februar 2013. 
После войны у себя на родине девушка была дважды осуждена за службу в Немецком Красном кресте: 11 июня 1946 г. к девяти месяцам тюремного заключения и пяти годам полицейского надзора, а 24 января 1950 г. - к лишению прав в объеме, предусмотренном ст. 123 Уголовного кодекса Бельгии (лишение всех избирательных прав, права на работу в юридической и образовательной сферах, на участие в политической газетной деятельности и создание любой культурной продукции, преследующей политические цели, права возглавлять политические объединения и занимать неоплачиваемые должности в общественных и профсоюзных организациях, занимать оплачиваемую государством должность служителя культа) ${ }^{28}$.

Вскоре после освобождения из заключения Люция вышла замуж за ветерана Национал-социалистического автокорпуса Ромео Лежена (родился 9 сентября 1921 г., умер в Вату в декабре 1987 г.) ${ }^{29}$. Занимала пост референта по связям с общественностью Центра бывших добровольцев Восточного фронта Фландрии. Кроме того, 10 лет занималась преподаванием кружевоплетения, работы ее учениц неоднократно экспонировались на выставках ${ }^{30}$.

Вообще же, северная часть Бельгии - голландскоязычная Фландрия - дала Немецкому Красному кресту наибольший контингент медсестер среди всех европейских стран. Всего в госпиталях на территории Германии и других европейских стран служили примерно 600 фламандок (в основном незамужних), средний возраст которых составлял от 18 до 25 лет $^{31}$.

По крайней мере еще одна из них была так же награждена Железным крестом II класса, получив его за последние бои в Берлине в апреле 1945 г. Ею была Марта Клемен, родившаяся 18 января 1922 г. в Антверпене и вступившая в Немецкий Красный крест в $1944 \Gamma^{32}$.

По ее воспоминаниям, 21 апреля 1945 г. в казармах дивизии СС «Лейбштандарт» в берлинском районе Лихтенфельд были собраны валлонские и фламандские санитары Немецкого Красного креста и сотрудники Национал-социалистического автокорпуса. Среди первых ей был известен только фламандец Тео Ван Реек (в Берлине получил ранение в лицо, после войны жил в бельгийском Вилрейке), а среди вторых - Джос Оп`т Ейнде, также ее земляк. Образовавшийся в казармах импровизированный госпиталь состоял, кроме того, из валлонского врача СС-штурмбанфюрера доктора Жакмана, работа которого при крайней ограниченности имеющихся ресурсов вызывала восхищение Клемен, и трех медсестер: самой Марты, фламандки Моники Клоотенс из Бергена и голландки Лени.

28 «Belgisch Staatsblad», 1 november 1946. P. 9036; «Belgisch Staatsblad», 19 juli 1950. P. 5406.

29 Письмо Вима Винкелера от 24 июня 2016 г. / Личный архив автора (ЛАА).

30 Ein flämisches Mädchen mit EK 2 // «Der Freiwillige» № 1, Januar/Februar 2013.

31 Peeters T. Het Sint-Maartensfonds. Een Vlaamse hulporganisatie en vereniging van voormalige vrijwilligers in nazi-Duitse (para-)militaire organisaties. Masterproef voorgedragen tot het behalen van de graad van Master in de Geschiedenis. Universiteit Gent, 2013. P. 29.

32 Письмо Вима Винкелера от 22 апреля 2016 г. / ЛАА. 
Из-за постоянного обстрела 180 раненых, в том числе находившихся в крайне тяжелом состоянии, были размещены в подвалах. Анестезирующих, перевязочных материалов и лекарств не было. Единственное, что мог персонал - три раза в день выдавать пациентам коньяк, запас которого они нашли в казарме. Там же оказались несколько мешков манки, которая, разведенная водой, служила основной пищей. На бинты рвали простыни из взломанной ими бельевой.

28 апреля девушки получили приказ доктора Жакмана оставить казарму. Однако они отказались выполнять его и бросать на произвол судьбы раненых. В итоге было решено тянуть жребий, остаться выпало Монике Клоотенс. Две другие сестры и около 40 способных идти раненых, разделившись на группы по 4 человека, стали выбираться из Берлина. Марте это удалось и, сопровождая военнослужащего СС Ричарда Рихтера, она смогла добраться до Фленсбурга, где они сдались американцам. Впоследствии Рихтер писал Клемен, однако та, находясь в заключении в Вилворде, не смогла ответить.

Как ей стало известно потом, при захвате казармы советские солдаты перебили всех находившихся там раненых, судьба Моники Клоотенс осталась неизвестной - послевоенные запросы ее родителей не принесли результата. Доктор Жакман, также оставшийся со своими пациентами, попал в советский плен, откуда смог бежать, однако был повторно пленен войсками США и провел длительный срок в бельгийских тюрьмах. После освобождения жил в немецком Эрлангене.

Среди раненых Марта видела еще одного фламандца, национальность которого определила по нарукавному щитку со львом, - молодого светловолосого человека 18-19 лет. У него было тяжелое ранение головы, и он не приходил в сознание. Личного опознавательного знака при нем не было, однако на шее он носил образок на черном шнурке, а на пальце - серебряное обручальное кольцо ${ }^{33}$.

Бывшая сестра Марта Клемен умерла 14 апреля 1982 г. в возрасте 60 лет ${ }^{34}$.

\section{Иностранные медсестры, награжденные крестом "За военные заслуги" и медалью "За военные заслуги"}

Крест «За военные заслуги», учрежденный 18 октября 1939 г. в двух степенях и в версиях с мечами и без, а тем более медаль данного ордена, введенная в наградную систему Германии в августе 1940 г., являлись менее высокими, но гораздо более распространенными, чем Железный крест наградами.

Они вручались за широкий спектр заслуг военного характера, включая выполнение служебных обязанностей под огнем и при авианалетах (при

\footnotetext{
33 Vincx J. Vlaanderen in uniform 1940-1945. Deel 2. Antwerpen, 2004. P. 241-242.

34 Письмо Вима Винкелера от 22 апреля 2016 г. / ЛАА.
} 
данных обстоятельствах вручался крест с мечами). Награждению орденом подлежали все категории граждан - военнослужащие, гражданские, сотрудники и члены военизированных, политических, общественных организаций, а также иностранные добровольцы, задействованные в военных и гражданских структурах Рейха. Медалью награждались исключительно гражданские лица, в том числе сотрудники промышленных и сельскохозяйственных предприятий, Красного креста, помощники и помощницы вспомогательной службы $\Pi \mathrm{BO}^{35}$.

Нередко наградой отмечались и медсестры-иностранки, среди которых была фламандка Мария (полное имя - Мария Адриана Петронелла) Ван Аерден, родившаяся 23 июля 1922 г. в нидерландском Берген-оп-Зоом ${ }^{36}$.

Эта девушка из Антверпена входила в группу из 25 первых фламандских медсестер Немецкого Красного креста, приступивших к занятиям на курcax в бельгийском Спа в январе 1943 г. и 5 февраля того же года отбывших в Германию для продолжения обучения в трех лазаретах Гамбурга. При этом учебная программа включала не только освоение практических навыков медицины, но и идеологическую подготовку.

Крестом «За военные заслуги» II класса с мечами Мария была награждена за выполнение долга в дни массированных налетов англо-американской авиации на Гамбург в августе 1943 г.: госпиталь, в котором она служила, был подожжен, сестры делали все зависящее от них для спасения раненых, неоднократно возвращаясь в огонь ${ }^{37}$. При этом Ван Аерден пострадала сама, получив отравление диоксидом углерода.

Пережив этот, один из самых разрушительных авиаударов войны, молодая фламандка погибла через несколько месяцев при советском налете на Таллинн в ночь с 9 на 10 марта 1944 г., служа в лазарете III танкового корпуса СС. Некоторые обстоятельства ее гибели были описаны в газете фламандских CC «De SS-man» (после войны статья была перепечатана в ветеранском журнале «Berkenkruis»). Согласно свидетельствам другой медсестры - Агнес Ван Донген - Мария дежурила в ночную смену, на которую заступила в 18.45. После поражения лазарета фугасными и зажигательными бомбами и возникновения пожара все свободные от службы сестры (в том числе и недавно сменившаяся Ван Донген) бросились выносить раненых. Один из уже находившихся на месте врачей сказал ей об оставшейся в здании раненой фламандской медсестре и, вместе с другими, Агнес бросилась за ней. Когда они нашли Ван Аерден, та была уже без сознания и сделать что-либо было невозможно - она умерла в тот же день ${ }^{38}$.

35 Lumsden R. Medals and Decorations of Hitler`s Germany. Shrewsbury, 2001. P. 29-31.

36 Письмо Вима Винкелера от 20 апреля 2016 г. / ЛАА.

37 Vlaamsche DRK-Hilfsschwester met het KVK / «Getrouwe Maldeghem» № 4, 23 januari 1944.

P. 1; Peeters T. Het Sint-Maartensfonds... P. 28-29.

38 Siemons S. Sterren die nooit tanen // «Berkenkruis» № 6, Juni 1983. P. 28-29. 
Могила Марии Ван Аерден находится на мемориальном кладбище Маарьямяе в Таллинне.

Родившаяся 26 февраля 1922 г. в Антверпене Ван Донген также была награждена крестом II класса с мечами ${ }^{39}$. К сожалению, дата награждения и его обстоятельства нам пока неизвестны.

Свою службу она начала 9 марта 1943 г., выехав в составе группы из 32 медсестер из Брюсселя в Спа, где три недели проходила обучение в санатории Немецкого Красного креста, а 28 числа того же месяца отбыла (вместе с 25 другими девушками) в Берлин. По прибытии на Потсдамский вокзал, они были отправлены для продолжения учебы в школу Рейхсфюрера в Гросс-Шульцендорфе, где находились до 2 апреля, после чего были разбиты на группы и отправлены для прохождения практики в тыловые госпитали. Агнес была распределена в больницу Августы (Берлин, Шарнхорстштрассе 3).

1 июля девушки снова были собраны вместе и отправлены в Пиритц для сдачи экзамена, состоявшегося спустя шесть дней. В итоге лишь 15 из них были зачислены в штат Немецкого Красного креста, получив броши сестер-хелферин, остальные отправились домой, как показавшие неудовлетворительные результаты. После этого последовало распределение: четыре фламандки (в том числе Хильде Докс и Симона Лабиа) вернулись в лазарет Гинденбурга в Берлине, так как были слишком молоды для отправки на фронт; две (Лизетта Каусе и Миа Штруф) должны были пройти дополнительный месяц практики, который пропустили из-за болезни; Мария Беекман и еще одна девушка получили назначение в Краков, одна была возвращена домой с формулировкой «не пригодна к работе сестры». Сама Ван Донген и две другие хелферин - Митси Деккер и Мария Ван Зундерт - были распределены в лазарет III танкового корпуса СС, отбыв в Мариенбад 10 июля. Там они прошли еще три месяца практики, по итогам которых получили статус «сестер-помощниц» (нем. Hilfsschwester) и соответствующие продолговатые броши.

В октябре того же года все три отправились в отпуск во Фландрию, из которого Митси и Мария по различным причинам в лазарет не вернулись. Ван Донген же в следующем месяце вместе со всем остальным персоналом лазарета отбыла в Хорватию, где они дислоцировались в 120 км от Загреба до января 1944 г., когда были переброшены на Восточный фронт. До февраля Агнес служила в полевом лазарете Хунгербурга под Нарвой, затем - в Таллинне, где, как писалось выше, пережила советский авианалет 9 марта, после которого до апреля лазарет III корпуса находился в Харикуле, а затем - в Вольпере ${ }^{40}$.

Среди раненых в лазарет поступали и фламандские добровольцы, один из которых-СС-унтершарфюрер Джеф Ван Хоутвен - оставил воспоминания о Ван Донген:

\footnotetext{
39 Письмо Вима Винкелера от 22 апреля 2016 г. / ЛАА.

40 Vincx J. Vlaanderen in uniform 1940-1945. Deel 2... P. 236-237.
} 
Мы лежали в военном лазарете Вольпере в Эстонии. Там шутили так, как не будешь шутить среди пасторов. Но когда сестра Агнес Ван Донген заходила в комнату, все говорили по-другому. И это было удивительно. Мы не задумывались об этом, но она создавала дистанцию между уродливым и чистым. Где она появлялась - появлялась и черта между чистым и непристойным. Она проехала вместе со связным в коляске его мотоцикла 150 км по твердому снегу, потому что узнала, что в другом лазарете умирает парень из Хобокена. Восемнадцать лет, и когда ему вводили противостолбнячное, он сказал, что, наверное, уже заразился. Теперь судорога корежила изнутри солдатское тело... Фламандская сестра все-таки пришла вовремя, чтобы помочь ему и закрыть глаза ${ }^{41}$.

В сентябре лазарет III танкового корпуса был морем эвакуирован из Таллинна в Кенигсберг, после чего несколько раз менял места дислокации в северной Германии, пока на Пасху 1945 г. не разместился в Нехлине. Конец войны застал Ван Донген в Шверине, в один из госпиталей которого она получила назначение незадолго до этого. 2 мая она вместе с остальным гарнизоном сдалась американским войскам ${ }^{42}$.

Еще одной из награжденных была латвийская медсестра Альвине Суна, бывшая сотрудница 2-й больницы Риги. Она работала в различных госпиталях на северном участке Восточного фронта, в частности, в Пскове, и отличилась в боях на Волховском фронте, когда расположенный в нескольких километрах от линии фронта госпиталь находился под артиллерийским огнем и авианалетами с советской стороны. Суна первой заметила попадание зажигательной бомбы на крышу здания и приняла меры по устранению опасности. В итоге весной 1944 г. она стала первой награжденной латвийской медсестрой, получив из рук командира 19-й латвийской дивизии оберфюрера СС Бруно Штреккенбаха крест «За военные заслуги» II класса с мечами ${ }^{43}$.

При этом очевидно, что спасение раненых от смерти в огне однозначно выходило за рамки простого выполнения служебного долга и поэтому являлось основанием для награждения Железным крестом. Однако подобное решение было «завернуто» вышестоящими инстанциями, несмотря на согласие немецкого медицинского начальства. Здесь могла сыграть свою роль как неприязнь к латышам некоторых региональных руководителей СС, в первую очередь командира оберабшнита СС «Остланд» обергруппенфюрера СС Фридриха Еккельна, так и нежелание вручать более высокую награду по половому признаку.

18 июня того же года медаль «За военные заслуги» получила другая сестра-латышка - Эрна Бомис. Про нее известно, что в 1941 г. она окончила

41 Siemons S. Sterren die nooit tanen // «Berkenkruis» № 6, Juni 1983. P. 28.

42 Vincx J. Vlaanderen in uniform 1940-1945. Deel 2... P. 237.

43 SS kaŗa ziñotājs Graudulis R. Kaṛa nopelnu krusts latviešu māsai / «Daugavas Vanagi» № 20, 19 maijs 1944. L. 1. 
школу медсестер при 2-й рижской больнице, а с апреля 1943 г. служила на фронте. Награждение также осуществлял Штреккенбах ${ }^{44}$.

В самом конце войны, 1 мая 1945 г., медалью «За военные заслуги» была награждена норвежская сестра-хелферин Ида Кёхлер из 504-го полевого лазарета 4-го танкового корпуса СС (ранее служила в лазарете СС в Минске). Сама медаль была вручена ей лишь 24 июня $1945 \mathrm{r}^{45}$.

\section{Награждение медсестер знаками отличия "Для восточных народов"}

Знаки отличия для восточных народов «За храбрость» и «За заслуги» были учреждены 14 июля 1942 г. для вручения отличившимся бойцам «восточных» (русских, украинских, казачьих, балтийских, туркестанских, татарских и кавказских) частей германской армии, а также коллаборационистам из числа гражданского населения. Они имели пять степеней - бронзовую, серебряную и золотую II, а так же серебряную и золотую I классов, предусматривавшие последовательное награждение от низших степеней к высшим. При этом уникальность награды для германской наградной системы была в том, что допускалось до трех вручений знака одной и той же степени, а также вручение высших степеней, минуя низшие ${ }^{46}$.

Общее количество русских, украинских и белорусских женщин, задействованных в медицинских учреждениях германской армии, было, несомненно, значительно. Однако каков был их статус и имели ли все они отношение к Немецкому Красному кресту?

Уверенно можно говорить, что статус полноценных хелферин получил сестринский персонал медицинских учреждений таких крупных формирований, как Русский охранный корпус Вермахта и 14-я украинская добровольческая дивизия войск СС «Галиция». К этой же категории можно отнести девушек из эмигрантских диаспор, в частном порядке поступавших в ряды Немецкого Красного креста.

Однако в значительной массе других эпизодов, касающихся представительниц «восточных» народов, проходивших службу в германских лазаретах на Восточном фронте, речь можно вести лишь о представительницах института так называемых «добровольных помощников» - «хиви» (нем. Hiwi), набранных из числа военнопленных санитарок Красной армии или местных жительниц. Например, в 1944 г. в одном из репортажей русской

44 Vtrsserž. N Uldriķa uzu. Apbalvojums latviešu māsai / «Daugavas Vanagi» №26, 30 jūnijs 1944. L. 8.

${ }^{45}$ Gripp Bay E. Historien om frontsøstrene... S. 125, 128.

46 Подробнее см.: Калинин К. А.Награды для «восточных народов». СПб., 1999. С. 1-6. 
коллаборационистской газеты «За Родину» рассказывалось о русских санитарках одного из немецких госпиталей, в частности, Клавдии Фирсовой:

Ее история подобна многим. В начале войны Клавдия была санитаркой в одном из батальонов Красной армии. Два года назад попала в плен. Немцы, узнав, что она санитарка, предложили ей работать в полевом лазарете. Девушка работала честно и добросовестно. Оценив ее труд, немецкое командование освободило ее из плена. Клавдия осталась работать при лазарете ${ }^{47}$.

Сопровождавшие статью фотографии свидетельствуют, что данные работницы (в основном так же из числа бывших пленных) даже не имели какойлибо униформы и были одеты в гражданское.

В нашем распоряжении имеется запрос начальника медицинской службы III танкового корпуса (моторизированный полевой лазарет 1/532) от 22 июля 1943 г. в подразделение тайной полевой полиции с просьбой провести проверку 4 девушек - «кандидаток в хиви»: Прасковьи Маркевич (18 лет), Валентины Крошнековой (22 года), Екатерины Юрасовой (20 лет) и Екатерины Долгополовой (18 лет). От полиции Невеля через семь дней был получен ответ, что про первую кандидатку им выяснить ничего не удалось, а вторая решила отказаться от своих планов, так как имела двух детей, которых не хотела оставлять в случае передислокации лазарета ${ }^{48}$.

Данный персонал, не являвшийся служащими Немецкого Красного креста и находившийся на содержании армии, однозначно не может являться предметом рассмотрения нашей работы. Это же касается и санитарок некоторых восточных добровольческих формирований Вермахта (в первую очередь казачьих), хотя в числе последних была, по крайней мере, одна, награжденная бронзовым знаком «За храбрость»: 19-летняя Мария Студенникова из действовавшей на территории Хорватии 1-й казачьей дивизии Вермахта ${ }^{49}$.

Вместе с тем известно, что, например, на территории Латвии были созданы подготовительные курсы для русских девушек, пожелавших пополнить ряды Немецкого Красного креста. Наиболее подробно в прессе освящалась деятельность подобных курсов в Даугавпилсе (созданных при активном содействии руководителя Русского национального комитета города священника Леонида Ладинского), первый выпуск которых состоялся в марте 1944 г. Директором курсов был русский врач доктор П. Н. Федоров, а непосредственно практическими занятиями руководила хелферин Немецкого Красного креста Елена Гержа. Также известно, что одним из лекторов выступал русский хирург Н. Петров. В течение 3,5 месяцев 30 слушательниц курсов

47 Льдова Х. В походном лазарете. Они выбрали правильный путь / «За Родину» № 92 (492), 25 апреля 1944 г. С. 4.

48 Российский государственный военный архив (РГВА). Ф. 1323. Оп. 2. Д. 292а. Л. 188.

49 Ульянов В., Шишкин И. Предатели. Облик. М., 2008. С. 470. 
проходили практическую и теоретическую подготовку, а после выпуска были распределены по лазаретам, где осуществляли медицинский уход за ранеными немецкими, русскими и латвийскими военнослужащими ${ }^{50}$. Насколько можно понять, девушки являлись русскими жительницами Латвии, хотя, возможно, среди них мог оказаться определенный процент беженцев с оставленной немцами территории современной России.

Достоверно известно о русской медсестре Ольге Долинской, награжденной серебряным знаком для восточных народов «За храбрость» II класса. Эта девушка служила на санитарном поезде, отошедшем со станции румынского Плоешти и атакованном войсками Румынии, перешедшей на сторону противников Германии.

В посвященной Ольге газетной статье не названа точная дата данного события, однако сказано, что поезд из 12 вагонов с ранеными отошел со станции в 12 часов 15 минут и через 9 км следования напоролся на перегородившие полотно дороги танки, одновременно попав под артиллерийский огонь $^{51}$. Принимая во внимание это, а также внезапный характер нападения, можно уверенно сказать, что речь идет о 24 августа 1944 г. Государственный переворот в Бухаресте, в результате которого был арестован фактический правитель страны премьер-министр Ион Антонеску, был осуществлен накануне, а известно о нем стало лишь поздно вечером. На следующий день румынские войска попытались штурмом взять центр нефтяной промышленности Плоешти, который обороняли, в основном, военнослужащие зенитных частей Люфтваффе, однако бои в районе города растянулись на несколько суток ${ }^{52}$.

Через 10 минут после остановки к вагонам подошли румынские солдаты, которые начали грабеж поезда, а затем подожгли вагоны. В этот момент Долинской удалось покинуть горящий поезд и скрыться в ближайшем лесу, после чего она в одиночку стала двигаться к своим в направлении венгерской границы:

Шли дни. Оля потеряла счет времени. Платье ее изорвалось, туфли давно брошены. Изредка выходя из леса, она вырывала картошку и ела ее сырой, не рискуя развести костер.

Днем, ориентируясь по солнцу, ночью по звездам, она шла на запад. Туда, к венгерской границе. Часто видела она, как по дороге проходили советские танки. Она слышала советские песни, которые пели ее соотечественники - русские люди, одетые в красноармейскую форму. Они проходили, их песня замирала и тогда Оля рисковала перейти дорогу и опять углубиться в лес.

50 Петрович М. С почином! // «Новый путь» № 5 (49), 15 марта 1944 г. С. 8-9; Петрович М. Милосердие. Самоотверженность и героизм русской женщины / «За Родину» № 70 (470), 27 марта 1944 г. С. 4.

51 Бибиков М. Наша девушка / «Воля народа» № 10, 16 декабря 1944 г. С. 3.

52 Axworthy M., Scafes C., Craciunoiu C. Third Axis, Fourth Ally. Romanian Armed Forces in the European War, 1941 - 1945. London, 1995. P. 178-179, 191-192. 
В итоге ей, уже в полубессознательном состоянии, удалось встретить группу из 124 русских добровольцев Вермахта под командованием лейтенанта Шевченко, которые, так же как и она, уже 10 суток выходили из окружения, и с ними еще через три дня перейти линию фронта ${ }^{53}$.

\section{Иностранные медсестры, отмеченные иными наградами}

Наградная система Третьего рейха отличалась крайним разнообразием, в частности, кроме непосредственно государственных наград существовали и ведомственные знаки отличия, к которым относилась распространенная среди медсестер медаль Немецкого Красного креста «За заботу о немецком народе». Получали ее и сестры-иностранки.

Одной из них была испанка Мария Кристина де Ориве Алонсо, родившаяся в 1919 г. в Мадриде. В 1941 г. данная девушка, будучи членом женской секции крайне правой партии «Испанская Фаланга», вступила в ряды медсестер 250-й добровольческой испанской («Синей») дивизии Вермахта. Впоследствии она говорила, что «ушла в Россию, потому что должна была сопровождать своих товарищей по парте, кто оставил классы. Для борьбы с коммунизмом».

До лета 1942 г. сестра-хелферин де Ориве служила в госпиталях в Порхове и Кенигсберге, после чего вернулась в Испанию. После возвращения она продолжала работать медсестрой, а в 1946 г. вышла замуж за Агустина Пайно Мэндикоагуэ, бывшего санитара 1-й противотанковой роты 250-й дивизии. В этом браке родилось девять детей. Умерла Мария Кристина летом 2012 г. в возрасте 92 лет. Как говорилось в некрологе, знавшим ее, она была известна как «большая любительница чтения, растений, фотографии, сотрудница местного прихода» 54 .

3 октября 1942 г. в норвежской газете «Свободный народ» было опубликовано интервью с упоминавшейся нами выше фронтовой сестрой Марии Ингебригсен, данное ей во время ее трехнедельного отпуска по семейным обстоятельствам. В отличие от большинства медсестер первого контингента, отправленных на южный участок Восточного фронта, она входила в группу из пяти девушек, назначенных сначала в Ригу, а затем - в один из прифронтовых районов группы армий «Север». Говоря о своих сослуживицах Анне-Марии Бьорнстадт, Магнхилд Лангфельд, Венке Варендорпф и Грете Штольц - Мария упоминала, что две последние были награждены немецкой «медицинской наградой за храброе поведение под Киркинесом» ${ }^{55}$. Вероятно, в данном случае речь так же идет о медали «За заботу о немецком народе».

53 Бибиков М.Наша девушка / «Воля народа» № 10, 16 декабря 1944 г. С. 3.

${ }^{54}$ Jacinto A. María Cristina de Orive, última enfermera de la División Azul / «El País», 26 septiembre 2012. P. 45.

55 De norske sykepleierskene ved fronten viser en enestående tapperhet og utholdenhet / «Fritt Folk» № 232, 3 oktober 1942. 
Медаль «За зимнюю кампанию на Востоке 1941-1942», которую получали военнослужащие и иные лица, служившие в период с 15 ноября 1941 г. по 15 апреля 1942 г. как минимум две недели непосредственно на линии Восточного фронта или же от 60 дней в прифронтовой полосе, была вполне распространена среди немецких медсестер. Однако для иностранок данная награда, вероятно, являлась достаточно редкой в силу того, что основная их масса поступила в ряды Немецкого Красного креста в более поздние сроки.

Но имелись и исключения, как, например, еще одна испанка из первого контингента медсестер «Синей» дивизии - родившаяся 14 октября 1915 г. в каталонском Сант-Садурни-д`Анойя Мария Монсерат Ромеу.

О ее биографии известно, что получив в 1934-1936 гг. образование медсестры в университете Барселоны, девушка 8 июля 1937 г. вступила в женскую секцию «Испанской фаланги»и с сентября 1938 г. принимала участие в испанской гражданской войне на стороне националистов генерала Франко, служа сначала в госпитале имени Генерала Молы в Сан-Себастьяне, а затем - в Военном госпитале Красного креста в Леганесе.

Вместе с другими записавшимися в испанскую дивизию медсестрами Мария покинула Мадрид в конце августа 1941 г. и через Париж, Штутгарт, Нюрнберг, Графенвор и Берлин отбыла на восток. Первоначально служила в испанском госпитале в Варшаве, затем - на Восточном фронте, в немецком лазарете Смоленска, а так же испанском в Порхове, Риге и Кенигсберге. Вместе с остальными медсестрами демобилизовалась 16 июля 1942 г. В июне 1945 г. вышла замуж за ветерана «Синей» дивизии Хуана Фернандеса де Лоаса, родив в этом браке восемь детей. Скончалась в Ронде в 2004 г. ${ }^{56}$

Согласно ее личной книжке испанской Вспомогательной военно-медицинской службы, участие во второй мировой войне принесло ей две награды: испанскую медаль «За кампанию в России» и немецкую медаль, обозначенную аналогичным образом (исп. Medalla de la Campaña de Rusia (alemana)) ${ }^{57}$. По нашему мнению, подобным образом была обозначена именно медаль «За зимнюю кампанию на Востоке 1941-1942».

\section{W jednym szeregu. Pielęgniarki cudzoziemki Niemieckiego Czerwonego Krzyża, odznaczone w okresie II wojny światowej}

\section{Streszczenie}

W artykule autor przeanalizował wybrane przypadki nadawania odznaczeń pielęgniarkom cudzoziemskiego pochodzenia, służącym w szeregach Niemieckiego Czerwonego Krzyża w okresie II wojny światowej. Problem nie został wyczerpany - niezbadanych pozostaje zarówno

56 Querol C. Onze mesos als fronts russos / «El 3 de vuit», 16 abril 2010. P. 41-43.

57 Личная книжка Вспомогательной военно-медицинской службы Марии Монсерат Ромео-Фернандес де Лоаса (копия) / ЛАА. 
wiele wątków z życiorysów dziewcząt i kobiet wymienionych w tekście, jak i okoliczności przyznawania im odznaczeń. Poza tym nieznana jest rzeczywista liczba cudzoziemskich pielęgniarek, które otrzymały w Trzeciej Rzeszy odznaczenia; prawdopodobnie była ona znacznie większa. Artykuł jest pierwszą próbą podjęcia tego tematu i stwarza podstawy dla dalszych badań historycznych nad tym złożonym i niewątpliwie ważnym dla nauki tematem.

Tłumaczenie Agnieszka Pospiszil

\section{Arm to arm. Foreign nurses in the German Red Cross awarded Nazi medals during World War II}

\section{Abstract}

The present study is an attempt to examine the cases of foreign nurses who worked for the German Red Cross during World War II and were awarded Nazi medals for their service. The article is not meant to be exhaustive - a number of issues are left pending that concern the biographies and circumstances of rewarding even of the girls and women mentioned in the study, Moreover, it is safe to say, that in reality the number of foreign nurses awarded the Third Reich medals was even higher.

The article is the first attempt to synthesise available information in a separate study and to create a basis for the further research by historians of this complex and undoubtedly important issue.

\section{Библиография}

Axworthy M. Scafes C., Craciunoiu C. Third Axis, Fourth Ally. Romanian Armed Forces in the European War, 1941-1945. London, 1995.

Blindheim S. Frontkjemperbevegelsen. Hovedoppgave i Historie. Universitetet i Oslo, 1974.

Degrelle L. Campaing in Russia. The Waffen SS on the Eastern Front. Institute for historical review, 1985.

Fonn M. Unnskyld, frontsøstre! // «Sykepleien» № 3, 12 mars 2015.

Fonn M. Hernoes N., Hofstad E. Hva skjedde med 1967-kullet? // «Sykepleien» № 18, 6 desember 2007.

Gogstad A. Gjemt eller glemt? Norske kvinner i tysk sanitetstjeneste under Den annen verdenskrig // «Michael» № 5, 2008. S. 307-308.

Gripp Bay E. Historien om frontsøstrene. De norske frontsøstrenes historie i et nytt lys. Masteroppgave i historie. Universitetet i Oslo, November 2014.

Hvorfol svek du oss - Nøklebye Heiberg? Den første kontigent frontsøstre / «Folk og Land» № 3, 1998.

Jacinto A. María Cristina de Orive, última enfermera de la División Azul / «El País», 26 septiembre 2012.

Klietmann K.-G. Auszeichnungen des Deutschen Reiches 1936-1945. Stuttgart,2004.

Kriegsberichter Hansjoachim Herzog Dänische DRK.-Helferin erhielt das EK. 2 / «Schlesischen Tageszeitung» № 71, 16 März 1945.

Lumsden R. Medals and Decorations of Hitler`s Germany. Shrewsbury, 2001.

Neulen H. W. An deutscher Seite. Internationale Freiwillige von Wehrmacht und Waffen-SS. München, 1992. 
Peeters T. Het Sint-Maartensfonds. Een Vlaamse hulporganisatie en vereniging van voormalige vrijwilligers in nazi-Duitse (para-)militaire organisaties. Masterproef voorgedragen tot het behalen van de graad van Master in de Geschiedenis. Universiteit Gent, 2013.

Querol C. Onze mesos als fronts russos / «El 3 de vuit», 16 abril 2010.

Schweizer J. Les auxiliaries de la Deutsches Rotes Kreuz. Uniforme et équipement, 1938-1945 // «Armes Militaria Magazine» № 314, Septembre 2011.

Siemons S. Sterren die nooit tanen // «Berkenkruis» № 6, juni 1983.

Solarz J. Breslau 1945. Warszawa 2007.

Taylor H. P. Vichinghi contro il bolscevismo. Il distintivo norvegese per I combattenti al fronte: in Frontkjempermerket // «Uniformi \& Armi» № 164, dicembre 2009.

Ungváry K. Battle for Budapest. One Hundred Days in World War II. London; New York, 2003. Verton $H$. In the fire of the Eastern front: the experiences of a Dutch Waffen-SS Volunteer, 1941-45. Mechanicsburg, 2010.

Vincx J. Vlaanderen in uniform 1940-1945. Deel 2. Antwerpen, 2004.

Vincx J. Vlamingen aan het Oostfront. Deel 2. Antwerpen, 1975.

Voss J. Black Edelweiss. A Memoir of Combat and Conscience by a Soldier of the Waffen SS. Bedford, 2002.

Vtrsserž. N. Uldriķa uzu. Apbalvojums latviešu māsai / «Daugavas Vanagi» № 26, 30 jūnijs 1944. Williamson G. World War II German Women's Auxiliary Services. Oxford, 2003.

Бибиков М. Наша девушка / «Воля народа» № 10, 16 декабря 1944 г.

Гофман И. Сталинская война на уничтожение: планирование, осуществление, документы. Москва, 2006.

Калинин К. А. Награды для «восточных народов». СПб., 1999.

Льдова X. В походном лазарете. Они выбрали правильный путь / «За Родину» № 92 (492), 25 апреля 1944.

Петрович М. Милосердие. Самоотверженность и героизм русской женщины / «За Родину» № 70 (470), 27 марта 1944.

Петрович М. С почином! // «Новый путь» № 5 (49), 15 марта 1944 г.

Ульянов В. Шишкин И. Предатели. Облик. Москва, 2008.

Центральный архив Министерства обороны Российской Федерации (ЦАМО РФ). Ф. 58. Оп. 18001. Д. 1311; Ф. 3402. Оп. 1. Д. 60.

Российский государственный военный архив (РГВА). Ф. 1323. Оп. 2. Д. 292а.

Самцевич Андрей, профессиональный историк. Исследует историю русской и украинской эмиграции в период Второй мировой войны, независимого Хорватского государства и женских вспомогательных служб Третьего рейха и Великобритании (ges5970@yandex.ru).

Samcewicz Andriej, zawodowy historyk zajmujący się rosyjską i ukraińską emigracją w czasie II wojny światowej, dziejami niepodległej Chorwacji oraz żeńskich służb pomocniczych w Trzeciej Rzeszy i Wielkiej Brytanii (ges5970@yandex.ru).

Samcevich Andrei, professional historian. Researcher into the history of the Russian and Ukrainian emigration during World War II, Independent state of Croatia and women's auxiliary services in Third Reich and the United Kingdom (ges5970@yandex.ru). 


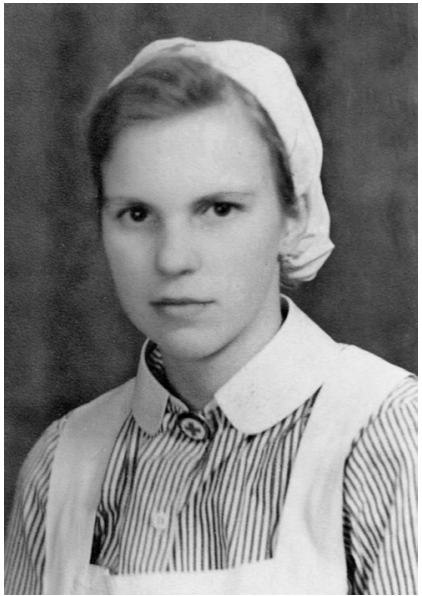

1. Сестра-хелферин

Немецкого Красного креста в служебной форме.

Источник: фото из коллекции автора.

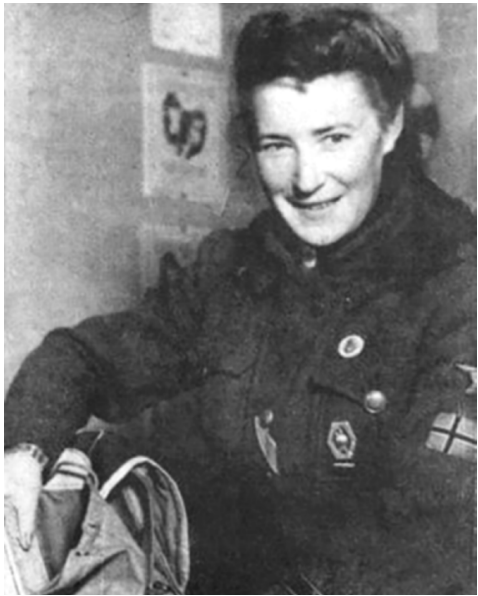

2. Анна Гунхильд Мокснес. На фотографии хорошо видны лента Железного креста II класса,

Знак фронтовика (на левом кармане), Знак фронтовой сестры (выше него) и манжетная лента 5-й танковой дивизии войск СС «Викинг», при которой она служила ранее.

Источник: «Illustrierter Beobachter» №15, 7 April 1945.

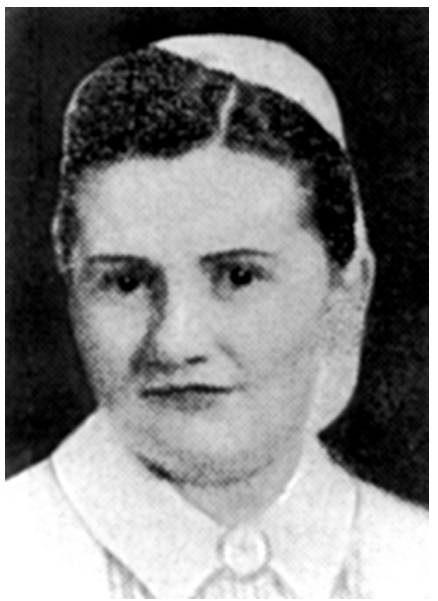

4. Марта Клемен.

Источник: фото любезно предоставлено Вимом Винкелером.

фильма «Die Oostfronters» (режиссер - Морис Де Вельде, телеканал VRT, 1989). 


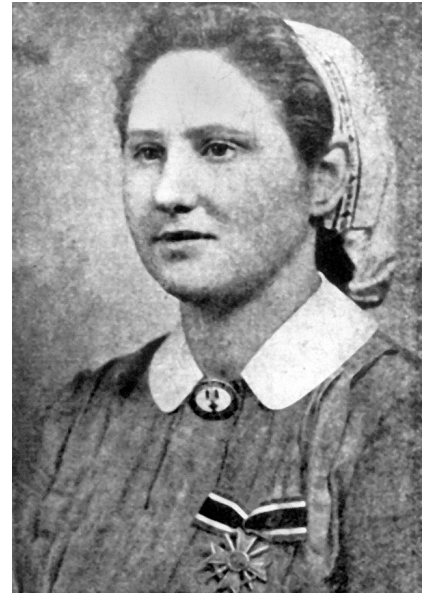

5. Мария Ван Аерден, вероятно, в день награждения. Виден характерный «женский» вариант крепления орденской ленты бантом.

Источник: фото любезно предоставлено Вимом Винкелером.

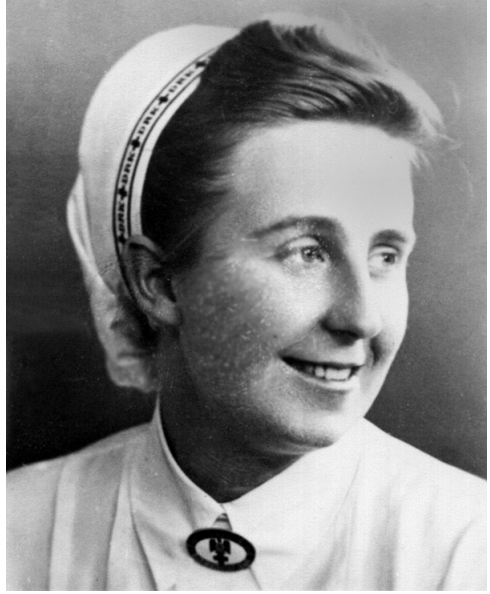

6. Агнес Ван Донген.

Источник: фото любезно предоставлено Вимом Винкелером.

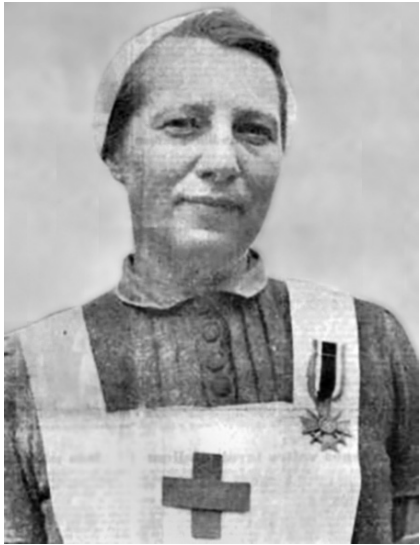

7. Альвине Суна

в день награждения.

Источник: «Daugavas Vanagi» №20, 19 maijs 1944.

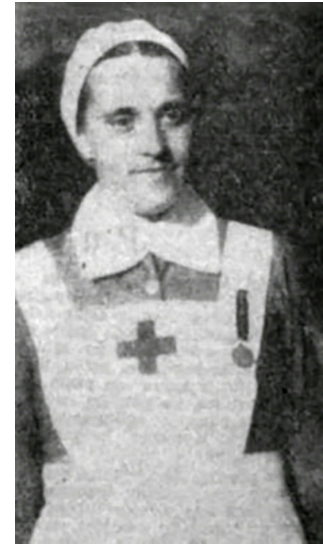

8. Эрна Бемис в день награждения. Источник: «Daugavas Vanagi» №26, 30 jūnijs 1944.

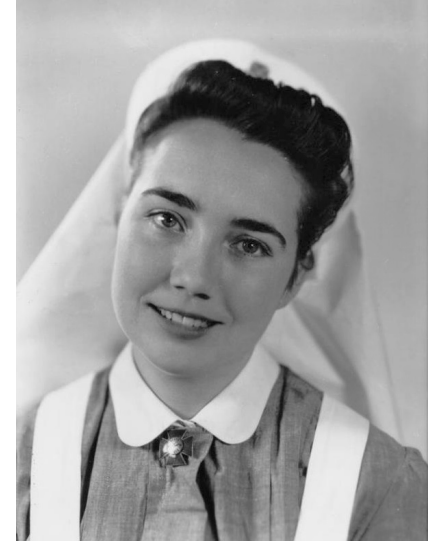

9. Мария Кристина де Ориве Алонсо.

Источник: Barrio A. P., Rubio M.P. Condecoraciones para la División Azul. Castellano, 2012. 